\title{
Electronic financial disclosure: Islamic banking vs conventional banking in GCC
}

\author{
Assoc. Prof. Dr Adel M. Sarea*, Dr. Abdalmuttaleb M.A. Musleh Al-Sartawi** and \\ Dr. Azam Abdelhakeem Khalid*** \\ Department of Accounting and Economics \\ College of Business and Finance \\ Ahlia University, Manama, Kingdom of Bahrain \\ *e-mail: adelsarea@yahoo.com / asarea@ahlia.edu.bh \\ **amasartawi@hotmail.com \\ ***Department of Accounting and Finance \\ Faculty of Management and Economics \\ Universiti Pendidikan Sultan Idris, Perak, Malaysia \\ azamabdelhakeem@gmail.com
}

\begin{abstract}
This paper examines electronic financial disclosure in Islamic banking vs conventional banking in Gulf cooperation council (GCC). A checklist was adopted to measure the level of electronic financial disclosure in Islamic banking vs conventional banking in GCC. The sample size consisted of total 90 banks in GCC (44 Islamic and 46 conventional) for the year 2017. The statistical analysis indicated that the overall level of of electronic financial disclosure (EFD) was 73 $\%$, and $78.6 \%$ by Islamic banks and conventional banks respectively. The results also report a significant and positive relationship with firm size, and an insignificant relationship with profitability, and age. This paper should be particularly relevant to central banking authorities considering in banking sector in GCC for strategizing policies in the future of EFD as well as to serve as a guide for academic EFD in banking sector in GCC.
\end{abstract}

Keywords: Financial accounting, Islamic banking vs conventional banking, Electronic Financial Disclosure, GCC

\section{Introduction and Literature Review: Need for the Study}

This study seeks to contribute significantly to all aspects of banking sector through the electronic financial disclosure (EFD) for both Islamic banking and conventional banking sector by determining the levels of disclosure of EFD. The need of disclosing more information through EFD are increasingly raised in the previous studies connected by different scholar from different countries including GCC countries, some of the most important of these incentives are: firstly, the need for the development of the appropriate institutional and regulatory framework. This is necessary to address the peculiar factors contributing to financial instability, while provide support and guide regarding the increasing globalization and liberalization with their potential crossborder effects. Secondly, it would enhance and facilitate timely, accurate and reliable information for investors (Al-Sartawi, 2017, and Janifer, 2003).

Despite the numerous challenges currently facing Islamic financial system, there is no doubt that the Islamic financial institutions (IFIs) comprising mainly of Islamic banking has steadfastly lay a formidable foundation in term of Internationally recognized Islamic financial transactions (AL-Rawashdah, 2009).In this regard, the impacts on the levels of EFD for both Islamic banking and conventional banking sector in term of external and internal influence on Islamic banking such as, foreign investment, 
globalization, international capital markets, international accounting firms and multinational organizations are due to the internal influences such as socio-cultural, national economic development levels, local capital markets and accounting professional body (Warsame, 2006).

Islamic banking plays a major and important role in the Islamic economy system. The significance of this study emerges from the need of full information through EFD for both Islamic banking and conventional banking sector. Therefore, financial disclosure in Islamic banking is required to be prepared fairly and carefully. This will further enhance and improve the efficient operation of Islamic banks as an important player in the economies and an unambiguous source of a comprehensive development.

In this regard, this study attempts to evaluate the extent of the levels for both Islamic banking and conventional banking sector by determining the levels of disclosure of EFD. Furthermore, this study contributes to the accounting literature in terms of the impact of the changes in EFD on investors, regulators, accountants, and the media as well as on several other dimensions with expectation of assisting in the establishment of checklist for banking system in its operation.

The findings obtained from the current study are therefore expected to fill the gap in the literature review and contribute towards a better understanding and acceptability of the electronic financial disclosure for both Islamic banking and conventional banking sector. Therefore, as a result of the rapid increase in number of investors and shareholders in the financial markets, the need of disseminating financial statements has increased to fulfill the satisfaction of shareholders. Moreover, the disclosing of earning information by large firms requires being fair, it should be disseminated widely and simultaneously to the investors by internet (Jorgensen \&Wingender 2004). Adopting EFD by companies has several benefits. Firstly, adopting internet financial disclosure enhances the companies' efficiency and attracts investors from all over the world. Secondly, EFD serves people who need to collect information about companies via internet. The users can easily access internet at any time, from anywhere and obtain efficient information inexpensively.

In addition, the adoption of EFD by the companies can enhance performance of these companies through the cooperating and exchanging of ideas, experiences and information between these companies. However, there are some factors that prevent companies from adopting EFD including: the necessity for a continuous updating of the information to benefit the users as much as possible, the illegality of requirements and the unwanted transparency in disclosing financial information. "Bin Au Khan \& bin Ismail" (2012) summarize the advantages of the internet financial disclosure as: the globalism, investors' communication and timelines, whereas the disadvantages of exposing financial information electronic include the problems of privacy and security, cost and experiences. Based on the above discussion, it is clear that the investigation of the extant of adoption EFD by the listed banks in GCC is important in this study.

Recently, there have been too many researchers investigating the extent of disclosing financial reports electronic among firms all over the world. Researchers were interested in examining the effect of some selected characteristics (e.g. size, profitability, liquidity, leverage... etc.) on EFD companies. In related study, Khadaroo (2005) conducted a comparative study that compares the internet disclosure practices of Malaysian listed companies with those in Singapore. The study also examines the implications of web technology for business disclosure and the challenge it poses for standard-setting bodies. The results show that the companies listed in Singapore has more countenance than those in Malaysia. Moreover, the Singapore companies characterized more potential to use the Internet than those in Malaysia. 


\section{Electronic Financial Disclosure: A GCC Perspective}

Several studies conducted in GCC discussing a number of issues related the EFD for both Islamic banking and conventional banking sector. For instance, the adoption of EFD to spread companies' information is a recent phenomenon and some studies consider its future implication. "Al-Motrafi" (2008) noted that the use of electronic financial disclosure in Saudi Arabia may involve rising the concerns of the accounting information disclosing, and this may lead users (such as auditors and regulators) to contribute in financial disclosure to extract regulations and moderate the use of EFD to fulfill statutory. Moreover, the researcher noted that firms may concentrate on innovation of EFD which may help companies induct a disclosure strategy to fulfill users satisfactory level (such as getting benefits by disseminating better information, and extant the companies communication). According to Al-Motrafi (2008) he examined the extent of using of EFD by Saudi public companies (113 companies); the researcher tested the influence of eight specific characteristics on disclosing financial disclosure attitudes. The study has found out that $95(84 \%)$ of the companies' own websites while only 51 companies (45\%) are adopting EFD. Moreover, the findings of the study have noted that none of these companies possess comprehensive financial information. In addition, the study has also stated that firm's size and stock market are the main variables that affect the mount of corporate information posed.

Another study conducted by Oyelere and Mohamed (2007) in Oman stock market, study showed that of the 142 firms, 59\% (84 companies) had an accessible Web site, and of these 84 companies only $31(36.9 \%)$ provided financial information on their home page. In related study, Al-Moghaiwli (2009) conducted a study to investigate the extent of internet disclosure practices of Qatar listed companies on the Doha Securities Market (DSM). The results indicated that 90.6\% (39 companies) had websites and a total of $28(71.8 \%)$ of these companies provided complete form for financial disclosure via internet. the ownership, firm size, and profit ratio structure are the main factors influencing EFD adoption. Another study conducted in Kuwait by “Alanezi”, (2009) A total number of 179 companies listed on Kuwaiti joint-stock (KSX) were investigated. The variables of company size, type of auditors, profitability, liquidity, and leverage were examined. The study reported that $56 \%$ of the listed companies disclose financial information.

Momany and Pillai (2013) conducted an empirical study in the United Arab Emirates to investigate the extent of volunteer (EFD) among (UAE) firms listed on the Abu Dhabi finance market (ADX). 65 companies were examined, and the researchers used UAE electronic search engines to collect data. The researchers tested eight (8) characteristics including the effect of profit ratios, firm's volume, firm's age, the type of ownership and its concentration, debt ratios, corporate governance, and asset ratios. The logistic regression analysis used as well as several statistical tests were done like correlation variance. The main results showed that $89 \%$ of the listed companies had special sites on the Internet whereas the other $11 \%$ did not have any sites. The study also found out that $60 \%$ of the firms on Abu Dhabi possessed web-sites provided financial information electronic while $40 \%$ of the firms did not provide corporate finance information online. In addition, the results showed that $91 \%$ of the companies provided comprehensive financial statements whereas $9 \%$ provided partial financial statements. In addition to that, the findings showed that profitability and corporate governance were the significant factors that affect the adoption of EFD.

A similar study conducted by Miniaoui \& Oyelere in UAE (2013) to investigate the determinants of disclosing corporate financial information online. The study stated that the firm size, industry sector, the leverage, and profitability were the most important variables of volunteer EFD. The study results showed, "larger companies with greater leverage are more likely to set up a website and use it for EFD than smaller less leveraged ones". The logistic regression analysis used to examine the significant factors of EFD by the firms. The study noted that the banking sectors, investment and finance sectors and insurance sector had the major portion (62\%) of EFD companies. 
In addition to that, Joshi \& Al-Modhahki (2003) conducted study in Bahrain and Kuwait to determine the extent of disclosing corporate financing information. A sample of 75 companies (Kuwait 42 and Bahrain 33) was selected. Six (6) characteristics were tested; company size, profitability, debt ratio, industry type, auditor size, and country effect. The researchers analyzed the collected data about these companies and deduced that $47.6 \%$ of Kuwait companies owned website, while $48.5 \%$ of Bahrain companies did. They also concluded that the size and industry were the most significant variables that affect adopting EFD. Another study was carried out by Mohamad \& Oyelere (2008) to examine the practices of disclosing corporate information via internet in Bahrain. The study was preparatory and limited since it didn't investigate an in-depth view of the potential practices. The researchers collected data available about all the 49 listed companies in Bahrain Stock Exchange (BSE). They used Google and Yahoo engines and telephone calls to investigate whether the listed companies own websites or not. The study reported that $40(81.6 \%)$ of the companies possess websites while only $27(67.5 \%)$ of these companies were adopting EFD. Moreover, the findings showed that 34 companies provided historical information about themselves and 34 provided information about their services and products, whereas 31 companies provided financial information. In addition, the researchers stated that only 25 companies posed both annual reports and financial highlights.

\section{Theory of Voluntary Disclosure: The Agency Theory}

The agency theory interprets why organizations voluntarily disclose information primarily for stakeholders and public in general. The organizations believe that contact with agents is a good means for monitoring actions and this contact can be best achieved by disclosure of proper information. According to agency theory, there are conflicts of interest between two parties; outsiders and insiders. These conflicts are more likely to occur in larger organizations (Mohammad and Monirul, 2012). This indicates that the advantage of disclosing information is correspondingly greater. The managers (insiders) usually need to be trustworthy to the shareholders (outsiders) through the reduction of agency cost by disclosing more information about the organization (Sweiti, and Attayah, 2013).

"Francis et al"; (2002) has argued that less outsider ownership results in less information asymmetry between the insider and outsider shareholders; therefore, ownership concentration reduces the need for strong corporate governance and transparency. According to "Zimbwa", (2005) companies with a greater concentration of shareholding are likely to have lower levels of transparency and thus not disclosing information whereas companies with higher leverage ratios are more likely to have higher levels of transparency and disclose more information as a result. This leads to the assumption that there is a relation between the firm's size, leverage and cost and benefits on the one hand and the disclosure of information on the other.

\section{Research Design and Methodology}

\subsection{Sample Selection}

The empirical study of the current research depends on a population which consists of all the listed banks in the GCC bourses for the year 2017. However, the required data were gathered from 90 banks (44 Islamic, and 46 conventional) out of 110 banks listed in the GCC bourses. Some of the banks were excluded from the study because they are suspended and closed, some of them their website was not functioning and some of them did not have an investor relations section on their websites. Moreover, the researchers used the banks' websites and the GCC Bourses websites to gather the data required for this study.

\subsection{Measuring the level of Electronic financial disclosure:}

For the current study the researchers have adopted a checklist used by Al-Sartawi 
(2016) Alrawahi \& Sarea (2016) \& Al jawder \& Sarea (2016) consisting of 90 items (71 items for content and 19 items for presentation) to measure the EFD. Therefore, the EFD index is based on binary, that is, if a bank reported an item which was included in the checklist it received a score of 1 and if the bank did not report an item, a score of 0 was allocated. Accordingly, the Index for each bank was calculated by dividing the total earned scores of the bank by the total maximum possible score appropriate for the bank. Below formula shows the way of calculating the EFD index.

$$
E F D=\sum_{i=1} \frac{d i}{n}
$$

\author{
Where: \\ di: disclosed item equals One if the bank meets the checklist item and Zero otherwise. \\ n: equals maximum score each bank can obtain.
}

\title{
5 Research Design and Methodology
}

\subsection{Dependent Variable}

Several research studies have addressed the issue of electronic disclosure in the GCC countries (Al-Sartawi, 2016, and Al-Sartawi, 2018). These studies have investigated the effect of several variables on EFD like corporate governance, and institutional investor. Yet there are negligible studies that actually investigate the association of firm characteristics with EFD Accordingly, this study would be an important contribution in filling the gap in the current literature by determining whether there is a relationship between the level of EFD and the type of banks that are listed in the GCC Bourses.

\subsection{Independent Variables}

\subsubsection{Type of Bank}

Previous studies conducted in several countries are used "type of bank" as independent variable, for instance, Heffernan \& Fue (2008) they used dummy for type of bank: whether national joint stocks, city commercials and rural commercials. This bank dummy variable will provide a measure of the relative performance of the selected banks. This study could help in filling the gap in the literature by determining whether there is a postive relationship between the level of EFD and the type of banks in GCC.

\subsection{Control Variables}

\subsubsection{Profitability (ROA)}

However, based on Singhvi and Desai (1971) companies disclose more information when its profitability is above industry average in order to signal to the owners about its strong position to survive. Many studies have examined the relationship between profitability and the level of EFD (Oyelere et al, 2003; Agboola and Salawu 2012; Agyei-Mensah, 2012; Adebimpe and Ikenna, 2013. Meanwhile, Ashbaugh et al. (1999), Ettredge et al. (2002), Xiao et al. (2004) found contradictory results that do not support this relationship.

\subsubsection{Firm size}

With regards to firm size, empirical evidence by Ashbaugh et al. (1999), Debreceny et al. (2002), Ferguson et al. (2002), Hossain et al. (2012), and Omran and Ramdhony (2016) suggest firm size as a determinant to explain EFD. According to Agboola and Salawu (2012), larger companies are more perceptible, and as a result, may be more likely to disclose more information. Similarly, Adebimpe and Ikenna (2013) argue that 
large companies usually operate over wide geographical areas and undertake many products along with several divisional units. Hence, it is assumed that they have wellbuilt information systems that enable them to trace both financial and non-financial information for operational, tactical and strategic purposes. Moreover, Agboola and Salawu claim that the arguments in the literature lend support to higher disclosure by larger firms.

\subsubsection{Age}

Finally, with regards to age, previous studies reveal that there is a positive relationship with the level of EFD: Akhtaruddin (2005), Al-Shammari (2007). Older companies may be more motivated to disclose such information, as the disclosure is less likely to hurt their competitive position (Agboola and Salawu, 2012) Therefore, older companies might have better and established reporting systems than newer companies.

Therefore, based on the signaling theory, and theoretical and empirical literature, this paper establishes the following hypothesis as:

H1: There is a positive relationship between the type of the banks (Islamic or conventional) listed in the GCC Bourse and the level of EFD.

\subsection{Model:}

The following regression model was used to test the hypothesis. The regression model was developed using the EFD as dependent variable, the type of banking as independent variable, and the firm characteristics as control variables.

$$
E F D_{i}=\beta_{0}+\beta_{1} B_{-} \text {Type }_{i}+\beta_{2} \text { ROA }_{i}+\beta_{3} L F S Z_{i}+\beta_{4} A G E_{i}+\varepsilon_{i}
$$

Where:

Code Variable Name

Dependent variable -:

EFD Electronic Financial Disclosure \%

\section{Independent Variables -:}

\section{B_Type Bank Type}

\section{Control Variables-:}

ROA Returned on assets

LFSZ Firm size

AGE Firm Age

घi $\quad$ Error

\section{Operationalization}

Total scored items by the company/Total maximum scores

This is a binary Wherein 1 means that the bank is Islamic and 0 conventional

Net income / Total assets Natural logarithm of Total Assets

The difference between the establishing date of the firm and the report date

\section{Research Findings}

\subsection{Descriptive Analysis}

As mentioned earlier, the level of EFD is measured by dividing the total score of every bank by the maximum probable scores. In 2000, the Financial accounting standards board (FASB) identified the two dimensions of financial reporting as both the content and presentation of information disclosed by companies' websites. Consequently, based on the adopted index, the maximum score of the EFD was 90 items constituting content dimensions of reporting and presentation dimensions. Where the content dimension included 71 items, the presentation dimension included 19 items.

The results shown in table (1) suggest that the level of EFD was differed between Islamic and Conventional Banks. The conventional banks level was $78.6 \%$ and the Islamic banks level was $73 \%$. This could be due to the characteristics and the regulation of conventional banks comparing to the Islamic banks, both types are working in GCC 
countries, but the Islamic banks still did not have its separate standers for disclosures. Overall, the results show that the level of electronic financial disclosure by the two types of banks can be considered as a fairly good level of reporting since the differences between them were not significant at the level of $5 \%$.

Table (1)

Level of electronic financial disclosure

\begin{tabular}{llllll}
\hline Bank Type & N. & EFD & \multicolumn{2}{c}{ Independent Samples Test } \\
\hline Islamic & & $\underline{\text { Mean }}$ & $\underline{\text { S. D }}$ & $\underline{\text { t-value }}$ & $\underline{\text { Sig }}$ \\
Conventional & 46 & .7308 & .19341 & & \\
\hline Total & $\mathbf{9 0}$ & $\mathbf{. 7 5 8 8}$ & $\mathbf{. 1 8 1 3 0}$ & $\mathbf{- 1 . 4 4 4}$ & $\mathbf{0 . 0 7 6 *}$ \\
\hline
\end{tabular}

* Difference is significant at the 0.10 level.

Additionally, the descriptive statistics for control variables, i.e. the firm characteristics, in table (2) show that the mean of ROA is 0.10 . As for the mean of firm size, i.e. Total Assets, it was 1.49 million, with a minimum of 367246 million and a maximum 1719741907. The normality distributions of total assets were skewed. Hence, natural logarithm was used in the regression analysis to reduce skewness and bring the distribution of the variables nearer to normality. Finally, the bank age ranges from 4 to 62 with a mean of 19 , indicating fairly young banks.

Table (2)

Descriptive statistics for dependent and control variables

\begin{tabular}{lllll}
\hline Variable & Min. & Max & Mean & S. D \\
\hline ROA & -.05 & .85 & .0997 & .12438 \\
Size & 367246 & 1719741907 & $1.49 \mathrm{E} 8$ & $2.669 \mathrm{E} 8$ \\
Age & 4 & 62 & 19.14 & 14.471 \\
\hline
\end{tabular}

\subsection{Validity}

To test the validity, the model of the study was checked for multicollinearity which involved conducting the Variance Inflation Factor (VIF). The VIF should be lower than 10 and tolerance should not be below 0.2 (Field, 2005). The VIF scores for each variable are reported in Table (3). The results indicate that since no VIF score exceeded 10 for any variable in the model, while no Tolerance score was below 0.2 . So, it was concluded that there is no threat of multicollinearity.

Table (3)

Collinearity Statistics Test

\begin{tabular}{lll}
\hline Variable & Tolerance & VIF \\
\hline Type & .933 & 1.072 \\
ROA & .739 & 1.354 \\
Size & .992 & 1.008 \\
Age & .771 & 1.297 \\
\hline
\end{tabular}

Additionally, the researchers conducted the Pearson correlation test to measure the correlation between the dependent and independent variables. The results of the pairwise correlation presented in table (4) below demonstrate a weak correlation between the variables where the correlation does not exceed 0.449 . 
Table (4)

Correlations Matrix

\begin{tabular}{llllll}
\hline Variables & EFD & Type & ROA & Size & AGE \\
\hline EFD & 1 & & & & \\
Type & -.152 & 1 & & & \\
& $(.152) *$ & & & & \\
ROA & .154 & .257 & 1 & & \\
& $(.148)$ & $(.950)$ & & & \\
Size & .317 & -.258 & .163 & 1 & \\
& $(.432)$ & $(.588)$ & $(.556)$ & & \\
AGE & -.274 & .163 & -.449 & -.333 & 1 \\
& $(.490)$ & $(.124)$ & $(.236)$ & $(.756)$ & \\
\hline
\end{tabular}

*. Sig. between brackets.

**. Correlation is significant at the 0.01 level (2-tailed).

\subsection{Testing the Hypotheses}

Table (5) reports the findings of the regression analysis of the model. These findings show that the value of calculated F-Statistic for the model is 2.799 at a confidence level $95 \%$, where the p-value for the model is less than $5 \%$ at 0.022 . This finding supports the significance of the regression model statistically.

Table (5)

Regression analysis

\begin{tabular}{llllll}
\hline & Type & ROA & Size & Age & \\
\hline Beta & -.126 & .169 & .303 & .027 & \\
t-statistics & -1.810 & 1.440 & 2.983 & .233 & \\
Sig. & .030 & .154 & .004 & .817 & \\
\hline R & $\mathbf{R}^{\mathbf{2}}$ & $\mathbf{A R}^{\mathbf{2}}$ & S. E & F-statistics & Prob. (F) \\
\hline 378a & .243 & .192 & .17278 & 2.799 & .022 \\
\hline
\end{tabular}

The results as shown in the above table indicate a negative relationship between the level of EFD and the type of bank (Islamic or conventional), which could be due to Islamic banks disclosing less electronic financial information when compared to conventional banks as indicated by the overall levels of EFD. Reasons for this could be due to the high experience and age associated with conventional banks. Moreover, there is no clear regulation for disclosure in Islamic banks, and at the same time the Islamic banks follow double regulations which include both the Islamic standards and the central banks standards.

The firm characteristics such as profitability indicate that there is a positive but insignificant association with EFD, as the significance levels of the Return on Assets (ROA) variable is 0.154 . This result is in line with the results reported by Ashbaugh et al. (1999), and Xiao et al. (2004). Thus, could be due to the profit and loss sharing (PLS) principle in Islamic banking when compared to conventional banks, where Islamic banks are protected and have more stable profits. Another reason could be related to the Islamic principle of trusteeship (Amanah) i.e. due to the trust between managers and investors, managers might not have the need to signal their justification for their compensation packages.

Regarding size, the study found a significant and positive relationship with EFD, i.e. significant at 0.004 as larger firms tend to have more resources than smaller firms, and therefore it is expected that they have efficient information systems that enable them to easily trace information for operational, tactical, and strategic purposes. This result is similar to Agboola and Salawu (2012), Hossain et al. (2012), and Omran and Ramdhony (2016).

This study also failed to find an association between age and EFD at a significance level of 0.817. This is in line with the results of Adebimpe \& Ikenna, (2013), and Yusuf, (2013) who also found an insignificant relationship with age. The insignificance of age 
shows that experience with investor relations does not necessarily encourage banks to undertake more advanced means of financial reporting such as EFD. One reason for this could be that when compared to conventional banks, Islamic banks in the GCC are relatively young.

Consequently, we can summarize that the level of EFD by the GCC banks has a positive relationship with size and a negative relationship with bank type. Moreover, it has a positive yet insignificant relationship with profitability and age.

\section{Conclusion and Recommendations}

This research study set out to examine and report on the extent and firm characteristics that determine the practices of EFD by Islamic banks vs conventional banks in the GCC countries. This paper is an important contribution to filling the gap in the literature, as there are a limited number of studies which deal with EFD from such a perspective. The paper creates awareness regarding EFD that might prove beneficial to the various stakeholders including investors, regulators and preparers of financial statements. Data was collected using the websites of 90 banks listed on the stock markets in the GCC countries for 2017. A checklist was adopted from Al-Sartawi (2016), Alrawahi \& Sarea (2016) \& Al jawder \& Sarea (2016) to compute the total level of EFD.

The index measured both the content and presentation dimensions of the websites and online reports. This study found that the overall level of EFD in the GCC by Islamic banks is $73 \%$, while the level of EFD by conventional banks was $78.6 \%$. The results report a significant negative relationship with bank type, and a positive relationship with firm size. On the other hand, the results show an insignificant relationship with profitability (ROA), and age. It can be concluded that that larger banks disclosed more financial information on their websites due to the availability of resources where they can benefit from the resulting lower costs. This is consistent with the agency theory that large firms attempt to reduce the high agency costs associated with information asymmetry between the management and investors by disclosing a large amount of information.

This study recommends that Islamic banks use the internet to improve their exposure and the availability of financial information when compared to conventional banks. For example, based on Agoobala and Salawu (2012) many of the processes that occur in remote places can be automated and fed into a firm-wide information system or intranet. Moreover, to promote the uniformity in disclosure by Islamic banks, both regulatory and professional bodies should jointly provide a template for EFD.

\section{References}

1. Adebimpe, O. U. \& Ikenna, E. A. (2013). Internet financial reporting and company characteristics: A case of quoted companies in Nigeria. Research Journal of Finance and Accounting, 4(12), 72-80.

2. Agboola, A. A., \& Salawu, M. K. (2012). The determinants of internet financial reporting: Empirical evidence from Nigeria. Research Journal of Finance and Accounting. 3(11).

3. AGBOOLA, A., A. \& SALAWU M., K. (2012). The Determinants of Internet Financial Disclosure: Empirical Evidence from Nigeria, Research Journal of Finance and Accounting, Vol. 3, No.11, 2012.

4. Agyei-Mensah, B. (2011). Corporate financial disclosure: Firm characteristics and the use of the internet as a medium of communication by listed firms in Ghana. Rochester: Social Science Research Network. doi: http://dx.doi.org/10.2139/ssrn.1887369. 
5. Agyei-Mensah, B.K. (2012). Corporate financial reporting: Firm characteristics and the use of internet as a medium of communication by listed firms in Ghana. African Journal of Business Management. 6(6), 2299-2309.

6. Akhtaruddin, M. 2005. Corporate mandatory disclosure practices in Bangladesh. The International Journal of Accounting, 40, pp. 399-422

7. Al jawder, N \& Sarea, A (2016) Determinations of Internet Financial Reporting: Evidence form Bahrain Bourse, Jordan Journal of Business Administration, Volume 12, No. 4, 2016, pp 935-960

8. Al-Akra M, Eddie I A and Ali M J (2010), "The Association between Privatization and Voluntary Disclosure: Evidence from Jordan”, Accounting and Business Research, Vol. 40, No. 1, pp. 55-74.

9. Al-Anezi, F., S., (2009). Factors Influencing Kuwaiti Companies' Internet Financial Disclosure. Journal of Economic and Administrative Sciences, Vol. 25 Iss: 2, pp. 1 - 23. Retrieved from: http://www.emeraldinsight.com.libweb.uob.edu.bh/journals.htm?issn=1026$4116 \&$ volume $=25 \&$ issue $=2 \&$ articleid $=17014762 \&$ show $=$ html.

10. Al-Htaybat, K., (2011), Users' Perceptions on Internet Financial Disclosure Practices in Emerging Markets: Evidence from Jordan, International Journal of Business and Management, Vol. 6, No. 9, doi:10.5539/ijbm.v6n9p170, retrieved from: http://www.ccsenet.org/journal/index.php/ijbm/article/viewFile/9891/8509

11. Almilia, L. (2009). DETERMINING FACTORS OF INTERNET FINANCIAL DISCLOSURE IN INDONESIA. Accounting \& Taxation, 1(1), 87-99. Retrieved from: http://eds.a.ebscohost.com.libweb.uob.edu.bh/ehost/pdfviewer/pdfviewer?vid=22\&sid=dfd bb460-4d95-4ecd-a6d8-3feec2394236\%40sessionmgr 4005\&hid=4111

12. Al-Moghaiwli, M., H. (2009) "A survey of Internet Financial Disclosure in Qatar", Journal of Economic and Administrative Sciences, Vol. 25 Iss: 1, pp.1 - 20. Retrieved from: http://www.emeraldinsight.com.libweb.uob.edu.bh/journals.htm?issn=1026-

$4116 \&$ volume $=25 \&$ issue $=1 \&$ articleid $=17014756 \&$ show $=$ html\#sthash. 7 w19rBH1 .dpuf by http://libwebserver.uob.edu.bh/en/.

13. Al-Motrafi, K., A., (2008). Internet Financial Disclosure in Saudi Arabia: Users Perceptions and Disclosures Aston University. Retrieved from: http://eprints.aston.ac.uk/15266/1/AlMotrafi\%2C_Khalid_A_2008.pdf

14. Alrawahi, F \& Sarea, A, (2016),"An investigation of the level of compliance with international accounting standards (IAS 1) by listed firms in Bahrain Bourse", International Journal of Islamic and Middle Eastern Finance and Management, Vol. 9 Iss 2 pp. 254 -276

15. Al-Sartawi, Abdalmuttaleb (2018) Online financial disclosure and firms' performance: Evidence from the Gulf Cooperation Council countries, World Journal of Entrepreneurship, Management and Sustainable Development, 14(2), 178-190.

16. Al-Sartawi, Abdalmuttaleb. 2016. Measuring the level of online financial disclosure in the Gulf Cooperation Council Countries, Corporate Ownership and Control, 14(1), 547-558.

17. Al-Sartawi, Abdalmuttaleb. 2017. The Effect of the Electronic Financial Reporting on the Market Value Added of the Islamic banks in Gulf Cooperation Council Countries, 8th Global Islamic Marketing Conference. Istanbul 4-6 May. International Islamic Marketing Association, Turkey

18. Al-Shammari, B. (2007). Determinants of Internet financial disclosure by listed companies on the Kuwait Stock Exchange. Journal of International Business and Economics. Vol. 7, Issue: 1, pp $162-178$.

19. Aly, D., Simon, J., \&Hussainey, K. (2010). Determinants of corporate internet disclosure: Evidence from Egypt. Managerial Auditing Journal, 25(2), 182-202. doi: http://dx.doi.org/10.1108/02686901011008972.

20. Ashbaugh, H., Johnstone, K. and Warfield. T. 1999. Corporate Reporting on the Internet. Accounting Horizons, 13(3): 241-257.

21. Basuony, Mohamed A. K. \& Mohamed, Ehab K. A. (2014). Determinants of Internet Financial Disclosure in GCC Countries. Asian Journal of Finance \& Accounting, Vol. 6, No. 1 (70-89).

22. Bin Au Khan, M., \& bin Ismail, N. (2012). VARIOUS ASPECTS OF INTERNET 
FINANCIAL DISCLOSURE: EVIDENCE FROM MALAYSIAN ACADEMICIAN. Journal of Global Business \& Economics, 4(1), 1-15. Retrieved from http://libwebserver.uob.edu.bh/en/

23. Bozcuk, A., E. (2012) "Internet financial disclosure : Turkish companies adapt to change", Managerial Finance, Vol. 38 Iss: 8, pp.786 - 800, DOI: 10.1108/03074351211239405, Retrieved from: http://www.emeraldinsight.com.libweb.uob.edu.bh/journals.htm?issn=0307$4358 \&$ volume $=38 \&$ issue $=8 \&$ articleid $=17041512 \&$ show $=$ html http://libwebserver.uob.edu.bh/en/

24. Chatterjee, B. \& Hawkes, L. (2008). Does internet disclosure improve the accessibility of financial information in a global world? A comparative study of New Zealand and Indian companies.Australasian Accounting Business and Finance Journal. Vol. 2, Issue 4, (32-56).

25. Cormier, D., Ledoux, M.-J. \&Magnan, M. (2009), "The use of Web sites as a disclosure platform for corporate performance". International Journal of Accounting Information Systems, Vol. 10, No. 1, pp. 1-24.

26. Debreceny, R., Gray, G.L. and Rahman, A. 2002. The determinants of internet financial reporting, Journal of Accounting and Public Policy, 21 (5): 371-95.

27. Ettredge, M., Richardson, V. J. and Scolz, S. (2002), Dissemination of information for investors at corporate web site. Journal of Accounting \& Public Policy, 21 (4-5), 357-369.

28. Ezat, A. and El-Masry A. (2008). The Impact of Corporate Governance on the Timeliness of Corporate Internet Disclosure by Egyptian Listed Companies. Managerial Finance, 34(2), 848-867.Information Systems Control Journal 1: 1-3.

29. FASB (Financial Accounting Standard Board) (2000). Electronic Distribution of Business Reporting Information, Business Reporting Research Project, available at: http://accounting.rutgers.edu/raw/fasb/brrp1.pdf.

30. Ferguson, M. J., Lam, K.C.K. \& Lee, G.M. (2002). Voluntary disclosure by state owned enterprises listed on the stock exchange of Hong Kong, Journal of International Financial Management and Accounting, 13 (2), 125152.

31. Heffernan, Shelagh and Fu, Maggie, The Determinants of Bank Performance in China (August 22, 2008). Available at SSRN: https://ssrn.com/abstract=1247713 or http://dx.doi.org/10.2139/ssrn.1247713

32. Jorgensen, R. D., \&Wingender Jr., J. R. (2004). A Survey on the Dissemination of Earnings Information by Large Firms. Journal of Applied Finance, 14(1), 77-84. Retrieved from http://libwebserver.uob.edu.bh/en/

33. Joshi, P. L. \& Al-Modhahki, J. (2003). "Financial Disclosure on the Internet: Empirical Evidence from Bahrain and Kuwait," Asia Review of Accounting, 11(1), Vol. 11 Iss: 1, pp.88 - 101 .

34. Khadaroo, M. I. (2005). Business disclosure on the internet in Malaysia and Singapore: A comparative study. The Corporate Communications: an international Journal; 2005; 10, 1 ; ABI/INFORM Global pg.58. Retrieved from www.emeraldinsight.com/1356-3289.htm

35. Khan, M.Noor A. \& Ismail, N. A. (2012). Various Aspects of Internet Financial Disclosure: Evidence from Malaysian Academician. Journal of Global Business and Economics. VOLUME 4, Issue 1 (1-15).

36. Laswad, F., Fisher, R., \&Oyelere, P. (2005). Determinants of voluntary Internet financial disclosure by local government authorities. Journal of Accounting \& Public Policy, 24(2), 101-121. doi: 10.1016/j.jaccpubpol.2004.12.006. Retrieved from http://eds.a.ebscohost.com.libweb.uob.edu.bh/ehost/detail?vid=29\&sid=dfdbb460-4d954ecd-a6d8-3feec2394236\%40sessionmgr4005\&hid=4111\&bdata $=$ JnNpdG U9ZWhvc3QtbGl2ZQ\%3d\%3d\#db=bth\&AN=17289583.

37. Malhotra, P., \&Makkar, R. (2012). A Study of Corporate Web Disclosure Practices in India. IUP Journal of Corporate Governance, 11(1), 7-19. Retrieved from http://eds.a.ebscohost.com.libweb.uob.edu.bh/ehost/pdfviewer/pdfviewer?vid=23\&sid=dfd bb460-4d95-4ecd-a6d8-3feec2394236\%40sessionmgr4005\&hid=4111 by http://libwebserver.uob.edu.bh/en/

38. Marston C (2003). Financial reporting on the internet by leading Japanese companies. Corporate Communication: Int. J., 8(1): 23-34. 
39. Marston, Claire. (2003) "Financial disclosure on the Internet by leading Japanese companies", Corporate Communications: An International Journal, Vol. 8 Iss: 1, pp.23 - 34.

40. Miniaoui, H. \&Oyelere, P. (2013).'Determinants of internet financial disclosure practices: Evidence from the UAE', Review of Pacific Basin Financial Markets and Policies, vol. 16, no. 4, pp. 1350026-1-1350026-25.

41. Mohammad N., Monirul A. H., (2012) "The voluntary disclosure of internet financial disclosure (EFD) in an emerging economy: a case of digital Bangladesh", Journal of Asia Business Studies, Vol. 6 No: 1, pp. $17-42$.

42. Momany, M.T\&Pillai,R. (2013). Internet Financial Disclosure in UAE- Analysis and Implications.Global Review of Accounting and Finance.Vol. 4. No. 2. Pp. $142-$ 160.Retrieved

from http://www.globalraf.com/static/documents/September/2013/8.\%20Munther.pdf

43. Momany, MT \& Al-Shorman, S 2006, 'Web-Based Voluntary Financial Disclosure of Jordanian Companies', International review of business research paper, Vol. 2, no. 2, pp.127-139.

44. O'Donovan, G. (2002) "Environmental Disclosures in the Annual Report: Extending the Applicability and Predictive Power of Legitimacy Theory". Accounting, Auditing and Accountability, Vol. 15, No. 3, pp. 344 - 371.

45. Ogden, S., and J. Clarke, 2005, "Customer Disclosures, Impression Management and the Construction of Legitimacy: Corporate reports in the UK privatized water industry", Accounting, Auditing and Accountability Journal, 18: 313-345.

46. Omran, M. \& Ramdhony,D. 2016. "Determinants of Internet Financial Reporting In African Markets: The Case Of Mauritius," Journal of Developing Areas, Tennessee State University, College of Business, vol. 50(4), pages 1-18.

47. Oyelere, P, Laswad F. and Fisher, R. (2003). Determinants of Internet Financial Disclosure by New Zealand Companies. Journal of International Financial Management and Accounting, 14(1), 26-63.

48. Oyelere, P., \& Mohamed, E. A. (2007). INTERNET FINANCIAL DISCLOSURE IN OMAN. Global Journal of Business Research (GJBR), 1(2), 45-54. Retrieved from http://content.ebscohost.com.libweb.uob.edu.bh/pdf9/pdf/2007/61L9/01Jun07/32639783.p $\mathrm{df} ? \mathrm{~T}=\mathrm{P} \& \mathrm{P}=\mathrm{AN} \& \mathrm{~K}=32639783 \& \mathrm{~S}=\mathrm{R} \& \mathrm{D}=\mathrm{bth} \&$ EbscoContent $=\mathrm{dGJ}$ yMNXb4kSeqLQ4y9f wOLCmr0yep65Ssqa4SraWxWXS\&ContentCustomer=dGJyMPGts1C3qLdMuePfgeyx4 4Dt6fIA by http://libwebserver.uob.edu.bh/en/

49. Pendley, J. A., \& Rai, A. (2009). Internet financial disclosure: An examination of current practice. International Journal of Disclosure \& Governance, 6(2), 89-105. doi:10.1057/jdg.2008.26. Retrieved from http://eds.a.ebscohost.com.libweb.uob.edu.bh/ehost/pdfviewer/pdfviewer?vid=5\&sid=dfdb b460-4d95-4ecd-a6d8-3feec2394236\%40sessionmgr4005\&hid=4111 by http://libwebserver.uob.edu.bh/en/

50. Pervan, I. I., \&Bartulović, M. M. (2012). INTERNET FINANCIAL DISCLOSURE COMPARATIVE ANALYSIS FOR SELECTED CEE COUNTRIES. Conference Proceedings: International Conference of the Faculty of Economics Sarajevo (ICES), 348$363 . \quad$ Retrieved from http://eds.a.ebscohost.com.libweb.uob.edu.bh/ehost/pdfviewer/pdfviewer?vid=33\&sid=dfd bb460-4d95-4ecd-a6d8-3feec2394236\%40sessionmgr4005\&hid=4111.

51. Pervan,(2005). Financial Disclosure on the Internet and the Practice of Croatian Join Stock Companies. Quotes on the Stock Exchanges Financial: Theory and Practice 29 (2), 159-174.

52. Pinch, S., \&Sunley, P. (2009). Understanding the role of venture capitalists in knowledge dissemination in high-technology agglomerations: a case study of the University of Southampton spin-off cluster. Venture Capital, 11(4), 311-333. Doi: 10.1080/13691060902972885 Retrieved from http://libwebserver.uob.edu.bh/en/

53. Poon, Pak-Lok, David Li, and Yuen Tak Yu (2003). Internet Financial Disclosure.

54. Pozniak, L. (2013). INTERNET FINANCIAL COMMUNICATION: EVIDENCE FROM UNREGULATED MARKETS OF BRUSSELS AND PARIS. International Journal of Business \& Finance Research (IJBFR), 7(5), 107-122. Retrieved from http://eds.a.ebscohost.com.libweb.uob.edu.bh/ehost/pdfviewer/pdfviewer?vid=22\&sid=dfd 
bb460-4d95-4ecd-a6d8-3feec2394236\%40sessionmgr4005\&hid=4111.

55. Rodrigues, L. L.; Menezes, C. (2003). Financial disclosure on the internet - the Portuguese case.RAE electron. vol.2 no.2 Sao Paulo July/Dec. 2003

56. Seetharaman, A., Subramanian, R., \&Seow, Y. S. (2005). INTERNET FINANCIAL DISCLOSURE: PROBLEMS AND PROSPECTS. Corporate Finance Review, 10(1), 2935. Retrieved from http://search.proquest.com/docview/198762980?accountid=26303.

57. Singhvi, S.S.\& Desai, H.B. (1971). An empirical analysis of the quality of corporate financial disclosure. The Accounting Review, 46 (1), 129-138.

58. Suchman, M. C. (1995), "Managing Legitimacy: Strategic and Institutional Approaches". Academy of Management Review, Vol. 20, No. 3, pp. 571-610.

59. Sweiti, Ibrahim M. \&Attayah, Osama F. (2013) Critical Factors Influencing Voluntary Disclosure: The Palestine Exchange "PEX"..Global Journal of Management and Business Research Finance.Vol. 13, Iss.6, pp8-16.

60. Tsang, E. (2001), "Annual Report Disclosure and Corporate Legitimacy Management: A Study of Singapore Companies' Responses to the Government's Call for Venturing Abroad", Asia Pacific Journal of Management, Vol. 18, No. 1, pp. 27-43.

61. Ujah, N. U., \&Okafor, C. E. (2011). UNLEASHING THE CRACKEN: DOES INTERNET FINANCIAL DISCLOSURE MATTER IN AFRICA? International Journal of the Academic Business World, 5(1), 87-97. Retrieved from http://eds.a.ebscohost.com.libweb.uob.edu.bh/ehost/pdfviewer/pdfviewer?vid=23\&sid=dfd bb460-4d95-4ecd-a6d8-3feec2394236\%40sessionmgr4005\&hid=4111.by http://libwebserver.uob.edu.bh/en/

62. Victoria, B., Madalina, P., Nicoleta, P., \& Carmen, S. (2009). VOLUNTARY INTERNET FINANCIAL DISCLOSURE AND DISCLOSURE - A NEW CHALLENGE FOR ROMANIAN COMPANIES. Annals of the University of Oradea, Economic Science Series, 18(3), 770-778. Retrieved from http://eds.a.ebscohost.com.libweb.uob.edu.bh/ehost/pdf viewer/pdfviewer?vid=23\&sid=dfd bb460-4d95-4ecd-a6d8-3feec2394236\%40sessionmgr4005\&hid=4111.

63. Xiao, J. Z., Yang, H. \& Chow, C. W. (2004), The determinants and characteristics of voluntary internet-based disclosures by listed Chinese companies. Journal of Accounting \& Public Policy, 23 (3), 191-225.

64. Xiao, J.Z., Yang, H., Chow, C.W. (2004), "The determinants and characteristics of voluntary internet-based disclosures by listed Chinese companies", Journal of Accounting and Public Policy, Vol. 23 No.3, pp.191-225.

65. Yusuf (2013). Internet corporate financial reporting: A study of quoted Nigerian companies. African Journal of Accounting, Auditing and Finance, 2(3) 233-259.

66. Zimbwa, Chipwa (2005). AN EMPIRICAL ASSESSMENT OF CORPORATE TRANSPARENCY IN ZIMBABWE, Centre for Corporate Governance and Regulation Working Paper Series. Bournemouth University. Retrieved from: http://ibal.bmth.ac.uk/pdf_docs/424.pdf 